\title{
Research on Undergraduate Teaching Reform Based on Overall Quality Management
}

\author{
Huizhen Zhang \\ School of Electrical Engineering \& Information \\ Northeast Petroleum University \\ Daqing, China \\ 149004028@qq.com
}

\begin{abstract}
Northeast Petroleum University always attaches importance to the quality of undergraduate teaching, and it has put strengthening quality assurance and monitoring system as the important initiatives which can comprehensively improve the quality of teaching over the years. The School strengthens the quality assurance and monitoring work for undergraduate teaching through improving the quality of teaching standards, guarding the teaching entrance areas strictly, establishing and improving the teaching training and guidance systems, improving the teachers', especially the new teachers', teaching levels and improving the quality of teaching and feedback mechanisms, etc. So it promotes the quality of undergraduate teaching.
\end{abstract}

Keywords-college; undergraduate teaching reform; overall quality management

\section{INTRODUCTION}

Improving the quality of teaching is the eternal theme of school, especially on the day which the enroll mental scale of higher education has expanded rapidly, stabilizing and improving the quality of teaching is the decisive factor of college survival and sustainable development. Grasping quality from the management has become the consensus, strengthening the quality's assurance and monitoring of teaching is the important management tool of stabling and improving the quality of teaching. Therefore, how to establish a set of quality assurance and monitoring system of teaching that it is both scientific, standardized, and suitable for the truth of our school has become an important issue which is discussed spread by universities. Since 2010, our school launched a research called "A research and practice about establishing and improving the quality's monitoring system of teaching" which is led by the Office of Academic Affairs[1]. We learn from enterprise-wide quality management model, and Emphasis on the use of quality management principles, for example the "Quality first , full participation, process control, prevention, continuous improvement", and so on, and take measures of "while research, while summary, while the implementation, while improving", we carries out extensive exploration about the components of teaching quality monitoring system and operation mechanism. After years of research and practice, our school has established a set of comprehensive, multi-level, multi-channel, multi-directional interaction, self-regulated teaching quality monitoring system and operation mechanism. And it produces good results in practice[2].

\author{
Keyong Shao \\ School of Electrical Engineering \& Information \\ Northeast Petroleum University \\ Daqing, China \\ 1783811235@qq.com
}

\section{The SignificAnce Of CONSTRUCTING TeAching PROCESS QUALITY MANAGEMENT SYSTEM}

In recent years, the scale of the local higher education as the country has been rapidly developed, and the quality of education has also been greatly improved. It makes its due contribution for the rapid, health and sustainable development of our country's economic and social and higher education's own reform and development. However, the quality of higher education can not completely meet the needs of economic and social development, and the professional settings and structure of many colleges and universities are not reasonable[3]. The students' practical ability and innovative spirit should be strengthened. The overall quality of teachers needs to be improved. The talent training mode, teaching content and methods need to be further changed. Therefore, it's an urgent need to take effective measures to further deepen the universities teaching reform, improve the capacity and level of personnel training and to better meet the economic and social development needs of high-quality innovative talents. Local colleges and universities implement the quality of undergraduate teaching project is to adhere to the scientific concept of development, full implementation of the CPC Central Committee and the State Council. The deployment of the important strategic decisions and initiatives are implemented through science and education strategy and talent and strong areas important part of the strategy. Quality engineering improve the quality of undergraduate teaching quality as the goal, to promote reform and resource sharing as a means. In accordance with classification guidance, encouragement characteristics, focusing on the principles of reform, strengthen the connotation construction, and enhance the quality of higher education in the local autonomous regions and overall strength[4]. Quality engineering consider full to improve teaching quality and complexity of the systemic determine the basic, overall, guiding the project as a breakthrough in the reform, in order to mobilize the enthusiasm and initiative of universities. It guides Colleges and universities the reform of education and teaching orientation. The quality of implementation of the project for the expansion of high-quality educational resources benefit from the surface. It forms emphasis teaching, emphasis on good quality environment and management mechanisms to achieve higher scale, structure, quality and efficiency of the coordinated development of great significance. 


\section{ESTABLISHING TEACHING PRINCIPLES Of TOTAL QUALITY MANAGEMENT}

1) Scientific principles. In recent years, in some universities in China, how to protect the quality of education and teaching has carried out consolidation and improved series of fruitful exploration, however, improvement of the teaching process and scientific quality management system established there is a great distance. Therefore, the university can not simply teaching process will be established quality management system as an administrative task view. And it should be regarded as a scientific behavior.The scientific spirit and attitude in the use of scientific theory under the guidance of the scientific method to operate.

2) Adhere to the principle of a positive attitude and safe mode of operation. Quality management of the teaching process is a comprehensive and the whole procedural quality management. It is involved in the establishment and operation of all aspects of education, and with a distinctive oriented. Therefore, we must pay great attention to the actual operation soundness.

3) Adhere to the principle of combining long-term perspective and implement step by step. The content of the teaching process management system is multifaceted. We should take full account of their actual situation and possibility for different universities. We should implement it Planned and step by step and gradually improve it through continuous accumulation and adjustment.

4 ) Adhere to the principle of combining the leadership attention and the active participation of manager and the majority of teachers. The establishment and operation of quality management system of teaching process requires the active participation of relevant departments of the school, teachers and students. In order to mobilize the enthusiasm of the majority of teachers and manager, we must find ways to continually enhance their understanding, turn the quality management of teaching process into the positive action of the majority of teachers and manager, and improve the quality of school education fundamentally.

\section{The CONSTRUCTION OF COMPREHENSIVE} UNDERGRADUATE TEACHING QUALITY MANAGEMENT SYSTEM

Our school has been constantly explored undergraduate teaching regulation, and we improve the quality of teaching as the school's important work. At present, it has formed a relatively complete teaching quality assurance and monitoring system which can continuously improve the teaching level of teachers[5].

\section{A. Establish the Teaching Quality Evaluation and Information Feedback System}

The main function of the teaching quality evaluation and information feedback system is that it can carry out effective monitoring and regulation for the quality of teaching, promote new teaching methods and reform measures, discover and solve the problem of the quality of teaching in times. According to the quality of undergraduate teaching objectives and requirements, the formation of teaching quality evaluation system. Unified curriculum in schools teaching quality evaluation (student section), the College is only responsible for its faculty's teaching and teaching management to evaluate the implementation of the requirements. The evaluation by the College Steering Group and Head of the Department responsible for the completion and evaluation according to the required quality standards, the teachers in the teaching process to evaluate the effectiveness of instruction. But whether it is the result of the evaluation of teaching or evaluation of the teaching process, its purpose is to reflect the status of the quality of teaching. Its purpose is to reflect the status of the quality of teaching, so as to provide the basis of further completing and improving the quality of teaching. So we establish the information feedback system of college teaching. As shown in the figure bellow:

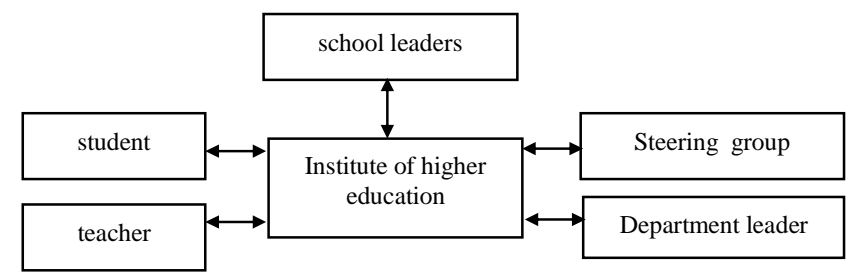

\section{FIGURE I. INFORMATION FEEDBACK SYSTEM OF TEACHING INFORMATION}

The main channels of the teaching quality information feedback include the quality information feedback of college steering groups' inspectional lectures; the quality information feedback of students and teachers through seminars and other forms; the Department (of) teaching secretary in charge and manage the process of teaching quality information feedback, and the quality of student evaluation results feedback. All information must be aggregated to College Teaching Education Division, which became teaching information collection and processing center.

\section{B. Strict the Teaching Entrance Areas Strictly, Ensure the Quality of Teaching}

1) Carry out pre-job training, school carries out teacher training for new teachers every year, hires experts introducing education, psychology, education technology and teaching experiences for new teachers, moreover, pre-service comprehensive training of teachers including professional ethics, Passers are eligible to apply courses taught.

2) Implementation of the new curriculum lecture. School carries out approval system for new commencement teachers and new course lecture, request teaching guidance committee of department or other expert organizations to listen and guide lectures for new commencement teachers in the post or external classroom teachers which are hired, to judge whether they are better able to undertake courses or not. New commencement department must fill in the evaluation forms for new commencement teachers, which record lecture process and approval comments. The departments which hire external teachers are responsible for safeguarding the quality of teaching, and select its teachers as campus contacts, who are 
responsible for coordinating and solving problems in teaching, ensuring the normal teaching.

3 ) Carry out the system of speaker teacher. School has strict audit requirements to the courses speaker teacher's qualification, the teachers who own lecturer or above lecturer professional titles can have the qualifications of speaker teacher. Some special professional such as art, sports and other technical courses, after approved by the department, teachers with bachelor's degree can also apply for speaker teachers. when individual new professional are short of speaker teachers, or new teachers don't have teaching experience, department can apply for current preparing cost which school single rows to hire outside experts or scholars to undertake curriculums, to guide the teaching of department teachers simultaneously in order to improve and ensure the quality of teaching.

\section{Establish Classroom Recording System, Strengthen Classroom Management, Ensure the Normal Operation Of Teaching}

Classroom teaching is the important form of teaching curriculum. The level of teaching quality largely depends on the successful or failure of classroom teaching. Therefore, the school teaching management departments should enhance the classroom management. Within two weeks of the new semester, Office of Academic Affairs should public the curriculum in all classrooms' teaching building publicity column and stating professional, grades, courses and teachers. On the one hand to facilitate teaching supervision and inspection, on the other hand to facilitate students' choice of study rooms. Under the conditions of the Credit System, because of the students elective freely, the traditional unit of professional teaching classes relatively discrete, so it is inconvenience for professional counselors grades check for classroom teaching especially for students attendance, this time, schools should implement classroom record-keeping systems, each classroom teaching should be responsible by the classroom teachers and the squad leader or class representative jointly, objective and accurately reflect the content of classroom teaching and students attendance. Duty monitor or class representative should hand in the classroom lessons teaching to faculty teaching secretary to record for future reference for every four weeks. At the end of each semester, classroom teaching units shall record receipt of all bound, as a teacher teaching workload assessment and statistical basis. Attendance by the student's faculty will commence where the faculty student absenteeism send a copy of the list, as the assessment of student learning reference.

\section{The Innovation of the Incentive Mechanism}

Establish the incentive system based on the function activity of teaching links, motivate teachers' teaching work actively, make the school always stay at a high level of job of teaching, improve teaching quality. First elect a best lesson plan at regular intervals, launch teaching competition "one class" according young teachers, organize the selection of classroom teaching quality excellence award. Second appraise excellent practice group guiding students practice every school year. elect the prize of excellent teachers students graduation project design thesis. Third regular select the virtue pacesetter according teachers, famous teachers, excellent teachers, the best teaching management cadres and the outstanding director of teaching and research section (laboratory), etc. Through the implementation of these incentives, greatly stimulated the enthusiasm of all teachers in teaching, promote the undergraduate teaching quality steadily improve.

\section{E. Flexible Information Feedback System}

Teaching information is the necessary for teaching management and quality monitoring, and it is the most important basis of decision-making organ to control. Total quality management requirements based on facts, regularly collect information about the teaching process and effects, find the problem that may be exist based on the information provided, to adjust teaching, Force along the direction of the plan for teaching in order to achieve the purpose of the management and control. After years of efforts, our faculty established a more comprehensive information feedback system, including the school (department) level of Contact party committee system, the leading cadre class system, student information feedback system, steering group attend a lecture,student evaluation of teaching system, office work meeting system, etc.

\section{F. Strengthen Construction of Teaching Staff and Improve the Overall Quality of the Teachers}

Teachers are the key to deepen teaching reform and to promote quality education. Quality and level of teachers determine the quality of personnel training and university education levels, so the school teaching staff must be placed in a position of paramount importance. According to the faculty building policies which is 'stability, introduction, training, topnotch, motivation', the point is to increase the number of full-time teachers and improve teacher education levels. Then we will establish a high-quality, reasonable structure, and streamlined, efficient and active teachers by focusing on positive and stabilizing talent, attracting talent, caring personnel, and training personnel with good talent. By vigorously promoting the reform of personnel distribution system, we will establish an open, fair, competitive and meritbased employment system, so that we can truly make fixed salary according to the jobs, make excellent workers paid more can promoted or demoted, can enter or exit, and can survival of the fittest. Award superior and eliminating the inferior. Inclined to the teachers (including teaching management staff), especially frontline teachers and key teachers, in professional title evaluation, the distribution of benefits and other aspects. Policy oriented majority of teachers devoting to jobs, the reforming zeal of teaching career, enhancing the cohesion and teaching activity of teachers, and form a favorable atmosphere of talents. At the same time, we should pay attention to strengthening teachers' professional ethics education and enhancing responsibility and mission of implementation of quality education. Not only teaching, but also educating people. Not only impacting scientific knowledge, but also teaching scientific thinking, scientific method, scientific spirit and ethics. To ease the shortage of basic course teacher caused by the expansion of our school, we can develop the potential teacher resources and improve operating efficiency through interscholastic mutual engagement, joint appointment, part- 
time teachers from the community; school retired teachers, the implementation of the graduate teaching assistant system and the other ways.

\section{G. Establish Undergraduates' Tutor System,Strengthen Guidance to Students' Study}

Under the condition of the system, university must be establish the undergraduate tutorial system, Undergraduate teacher's main job is to introduce the professional features, development trends and the social demand to students, Combined with professional training objectives, help students to correct learning attitude, arouse the enthusiasm for learning, Set up the professional thought. Teacher must be familiar with every students who is to be guided to know the students' interest, hobbies, special skill, dynamic, learning situation, the degree of intelligence and ability in many aspects, According to the specific situation of the students, guiding students to working out a reasonable study plan, guiding students to selecting course, Guiding students to carry out the social practice and scientific research, etc. university should employ lecturer or above as undergraduate advisor, university should strengthen the education of tutor, training and management about student. Supervise the teacher completed goal dutifully.

\section{H. Open Characteristic}

Under the condition of the system, university must be establish the undergraduate tutorial system, Undergraduate teacher's main job is to introduce the professional features, development trends and the social demand to students, Combined with professional training objectives, help students to correct learning attitude, arouse the enthusiasm for learning, Set up the professional thought. Teacher must be familiar with every students who is to be guided to know the students' interest, hobbies, special skill, dynamic, learning situation, the degree of intelligence and ability in many aspects, According to the specific situation of the students, guiding students to working out a reasonable study plan, guiding students to selecting course, Guiding students to carry out the social practice and scientific research, etc. university should employ lecturer or above as undergraduate advisor, university should strengthen the education of tutor, training and management about student. Supervise the teacher completed goal dutifully.

\section{SUMMARY}

Above all, we can come to the conclusion that the total quality management of higher school's teaching is the quality management system which is put the quality of teaching as the center, be attached importance to by leaders, be implemented by organizations, have the perfect institution, be participated by the entire personnel, be implemented through the whole process, feedback the information, monitor the process, have the perfect system.

\section{ACKNOWLEDGMENT}

This research was financially supported by the Key Topic of Heilongjiang Province of China (Grant NO.GBB1212018)

\section{REFERENCES}

[1] B. Zhang, N. Wei, and L. Gao, "Analysis Bilingual Teaching Model and Teaching Quality Assessment Index System," 2010 2nd International Symposium on Information Engineering and Electronic Commerce, Ternopil, Ukraine, pp. 400-403, (2010).

[2] $\mathrm{Xu}$ jiandong,Wang haiyan,Hu zong. "On the innovation of open experiment management mode in colleges and universities," Experimental Technology and Management,2009, vol.26, No.2, pp.2226.

[3] Han Furong, Management Science Of Modern Quality, Mechanical Industry Press, pp2, August 2007

[4] Liming Yang, Yansong Xue. "Modern Teaching Quality Management concepts and Innovations of Management System," 2010 International Conference on E-Health Networking,Digital Ecosystems and Technologies,pp.228-231

[5] So Young Sohn *, Yong Han Ju.Conjoint analysis for recruiting high quality students for college education,"Expert Systems with Applications 37 (2010) 3777-3783 